Szkoła Wyższa Psychologii Społecznej, Warszawa

\title{
Wolność wypowiedzi prasowej a zniewaga
}

Przestępstwo zniewagi chroni godność człowieka (część wewnętrzną) przed takimi naruszeniami, ,które według zdeterminowanych kulturowo i powszechnie przyjętych ocen stanowią wyraz pogardy dla człowieka niezależnie od odczuć samego pokrzywdzonego"1. Przestępstwo to, określane także w doktrynie jako obraza, polega na ubliżeniu komuś, obraźliwym zachowaniu się wobec kogoś ${ }^{2}$. W doktrynie, na gruncie prawa cywilnego toczył się niegdyś interesujący spór czy o fakcie naruszenia czci winny decydować przesłanki subiektywne, czy też obiektywne. Za pierwszą z tych koncepcji opowiedział się S. Grzybowski ${ }^{3}$. Zwolennikami drugiej z koncepcji są J. Panowicz-Lipska i A. Szpunar ${ }^{4}$. W literaturze zwraca się uwagę, że przyjęcie kryteriów obiektywnych jako decydujących o zaistnieniu zniewagi rodzi w praktyce problemy, gdyż niekiedy użyte z zamiarem znieważenia słowo obiektywnie nie jest pejoratywne, lecz dla obu stron ma ono sens obelżywy np. termin „rusałka” oznacza nimfę wodną, boginkę leśną, ale na niektórych obszarach Polski jest synonimem kobiety lekkiego prowadzenia się, takiej którą „cała wieś rusała”. W. Kulesza wskazuje, iż sprawca zniewagi może używać zwrotu, który według powszechnego rozumienia nie jest obelżywy, ale wypowiadający go wie, że w określonym środowisku przypisuje mu się poniżającą treść np. nazwanie lekarza mianem „konował”.

Przez wiele dziesięcioleci w przepisach ustaw karnych nie umiano konsekwentnie przeprowadzić rozróżnienia między zniewagami a zniesławie-

1 W. Kulesza, Zniesławienie i zniewaga (ochrona czci i godności osobistej człowieka w polskim prawie karnym - zagadnienia podstawowe), Warszawa 1984, s. 169.

2 P. Hofmański, J. Satko, Przestęstwa przeciwko czci i nietykalności cielesnej. Przeglad problematyki. Orzecznictwo (SN 1918-2000). Piśmiennictwo, Kraków 2002, s. 44.

3 S. Grzybowski, Ochrona dóbr osobistych, Warszawa 1957, s. 87.

4 J. Panowicz-Lipska, Majatkowa ochrona dóbr osobistych, Warszawa 1975, s. 29 i n.; A. Szpunar, Ochrona dóbr osobistych, Warszawa 1979, s. 107-129. 
niami. Rozróżnienie tych przestępstw utrwaliło się dopiero w czasach nowożytnych. W polskim Kodeksie karnym z 1932 r. przestępstwo zniesławienia, zwane także przestępstwem obrazy, zostało sformułowane w treści art. $156 \S 1$ k.k. z 1932 r. Po wejściu w życie Kodeksu karnego z 1969 r. przestępstwo zniewagi zostało ujęte w art. 181 k.k. z 1969 r., który z założenia miał chronić część wewnętrzną czyli godność człowieka.

Odróżnienie zniesławienia i zniewagi w praktyce może powodować i powoduje kłopoty. W judykaturze, jeszcze przed wejściem k.k. z 1932 r. podkreślano, że „rysem zasadniczym przestępstwa zniewagi (obelgi) jest świadome pomiatanie godnością osobistą jakiegoś człowieka przez poniżające tę godność, a skierowane do tej osoby słowa". Zauważano, że istotą zniesławienia jest nastawanie na dobre imię człowieka, natomiast istotą zniewagi pogardliwe jego traktowanie. Podnoszono, że zależnie od kontekstu w tych samych wyrażeniach może tkwić zniesławienie bądź obelga. Wskazywano jednocześnie, że pod pojęciem zniewagi należy rozumieć działanie zmierzające do pohańbienia czci osoby, przy czym różnica między obrazą a zniewagą zasadza się na tym, że sprawca chcąc poniżyć godność osobistą pokrzywdzonego znieważa go hańbiącymi słowami, ale nie przypisuje mu ani czynu przestępnego, ani udziału w postępku hańbiącym ${ }^{5}$. W literaturze podnoszono na tle regulacji z 1969 r., że zniesławienie stanowi postawienie zarzutu zracjonalizowanego, dotyczącego postępowania lub właściwości pokrzywdzonego, które mogą poniżyć go w opinii publicznej lub narazić na utratę zaufania potrzebnego dla danego stanowiska, zawodu lub rodzaju działalności. Natomiast sprawca zniewagi formułuje zarzut obelżywy lub ośmieszający, stawiając go w formie niezracjonalizowanej ${ }^{6}$. W doktrynie podnosi się, że obelżywy lub ośmieszający zarzut postawiony w formie niezracjonalizowanej, np. przez określenie „bałwan”, stanowić będzie jedynie naruszanie godności osobistej, nie pociagając za sobą dla pokrzywdzonego konsekwencji społecznych $\mathrm{w}$ postaci poniżenia $\mathrm{w}$ opinii publicznej lub utraty potrzebnego

5 Wyrok SN z dnia 24 marca 1926 r., sygn. akt II K 150/26, OSNK 1926 poz. 44; wyrok SN z dnia 9 października 1931 r., sygn. akt I K 886/31, RPiE 1932, Z. 1 , s. $154-155$.

6 B. Kunicka-Michalska w: B. Kunicka-Michalska, J. Wojciechowska, Przestęstwa przeciwko wolności, wolności sumienia $i$ wyznania, wolności seksualnej $i$ obyczajności oraz czci $i$ nietykalności cielesnej. Rozdziały XXIII, XXIV, XXV i XXVII Kodeksu karnego. Komentarz, Warszawa 2001, s. 246-247; J. Waszczyński, Zniewaga, w: System prawa karnego t. IV, O przestępstwach w szczególności, cz. 2, red. I. Andrejew, Wrocław-Warszawa-Kraków-Gdańsk-Lódź 1989, s. 114. 
zaufania, stanowiąc zniewagę a nie zniesławienie. Zarzut zracjonalizowany, godzący w dobre imię człowieka stanowi zniesławienie. Taki charakter ma nazwanie kogoś „złodziejem” czy „łapownikiem”. Zauważa się także, że możliwa jest sytuacja, w której jeden i ten sam czyn sprawcy stanowić będzie zarówno zniesławienie, jak i zniewagę ${ }^{7}$. Przestępstwo zniewagi jest niewątpliwie czynem godzącym w cześć człowieka i w związku $\mathrm{z}$ tym podobne jest do przestępstwa pomówienia.

W doktrynie wskazuje się, iż różnice między przestępstwem zniesławienia $\mathrm{z}$ art. $212 \mathrm{k} . \mathrm{k}$. a przestępstwem zniewagi polegają po pierwsze na tym, że zniewaga może dotyczyć konkretnego człowieka, natomiast pomówienie także grupy osób, instytucji, osób prawnych oraz jednostek organizacyjnych niemających osobowości prawnej. Po drugie, zniewaga polega na obraźliwym zachowaniu, najczęściej na użyciu słów obelżywych. Zachowanie to i obelżywe słowa mogą, ale nie muszą zawierać zarzutów. Pomówienie natomiast zawiera określoną treść, w której sformułowany został zarzut wobec innej osoby. Po trzecie, zniewaga może nastąpić $\mathrm{w}$ formie gestu bądź wizerunku, natomiast pomówienie powinno stanowić określona wypowiedź pisemną lub ustną zawierającą określone zarzuty. Po czwarte, zniewaga musi być skierowana bezpośrednio lub pośrednio do osoby znieważonej, pomówienie - zwłaszcza publiczne - musi być skierowane do innej osoby niż ta, której dotyczy ${ }^{8}$.

Niezależnie od zniewagi, o jakiej mowa w treści art. 216 Kodeks karny przewiduje odpowiedzialność za znieważenie określonych podmiotów, przedmiotów oraz miejsc. Tak więc można ponieść odpowiedzialność za: publiczne znieważenie Narodu lub Rzeczpospolitej Polskiej (art. 133 k.k.); publiczne znieważenie Prezydenta Rzeczpospolitej Polskiej (art. 135 § 2 k.k.); znieważenie na terytorium Rzeczypospolitej Polskiej głowy obcego państwa lub akredytowanego szefa przedstawicielstwa dyplomatycznego takiego państwa albo osoby korzystającej z podobnej ochrony na mocy ustaw, umów lub powszechnie uznanych zwyczajów międzynarodowych (art. 136 § 3 i 4 k.k.); publiczne znieważenie znaków państwowych (art. $137 \S 1$ k.k.); publiczne znieważenie przedmiotu czci religijnej lub

7 J. Waszczyński, Zniewaga, w: System prawa karnego, t. IV: O przestęstwach w szczególności, cz. 2, red. I. Andrejew, Wrocław-Warszawa-Kraków-Gdańsk-Lódź 1989, s. 114; podobnie wyrok SN z dnia 9 października 1931 r., sygn. akt I K 886/31, RPiE 1932, nr 1.

8 J. Wojciechowski w: A. Wąsek, R. Zawłocki, Kodeks karny. Część szczegól$n a$, t. I, wyd. 4, Warszawa 2010, s. 13-45. 
miejsca przeznaczonego do publicznego wykonywania obrzędów religijnych (art. 196 k.k.); znieważenie funkcjonariusza publicznego lub osoby do pomocy mu przybranej podczas i w związku z pełnieniem obowiązków służbowych (art. $226 \S 1$ k.k.); publiczne znieważenie konstytucyjnego organu Rzeczypospolitej Polskiej (art. $226 \S 2$ k.k.); publiczne znieważenie grupy ludności albo poszczególnej osoby z powodu jej przynależności narodowej, etnicznej, rasowej, wyznaniowej albo z powodu jej bezwyznaniowości (art. 257 k.k.), znieważenie pomnika lub innego miejsca publicznie urządzonego $\mathrm{w}$ celu upamiętnienia zdarzenia historycznego lub uczczenia osoby (art. 261 k.k.); zwłok, prochów ludzkich lub miejsca spoczynku zmarłego (art. $262 \S 1$ k.k.), znieważenie przełożonego przez żołnierza (art. $347 \S 1$ k.k.); znieważenie przez żołnierza innego żołnierza nie będącego jego przełożonym w związku z pełnieniem przez niego obowiązków służbowych (art. 348 k.k.); znieważenie przez żołnierza podwładnego (art. 350 § 1 k.k.); znieważenie przez żołnierza młodszego albo równego stopniem żołnierza, o krótszym okresie pełnienia służby wojskowej (art. 353 k.k.).

W treści art. 216 k.k. zostały określone dwa typy przestępstwa zniewagi: typ podstawowy (art. $216 \S 1$ k.k.) oraz kwalifikowany, polegający na popełnieniu tego czynu za pomocą środków masowego komunikowania (art. $216 \S 2$ k.k.). W § 3 art. 216 k.k. uregulowano odpowiedzialność za zniewagę w przypadku, gdy została ona sprowokowana, czyli wywołało ją wyzywające zachowanie pokrzywdzonego albo jeśli pokrzywdzony odpowiedział naruszeniem nietykalności cielesnej lub zniewagą wzajemną. W $\S 4$ art. 216 k.k. wskazano na podstawę orzeczenia nawiązki, a w $\S 5$ art. 216 wskazano, że ściganie odbywa się z oskarżenia prywatnego. W Kodeksie karnym z 1932 r. przestępstwo zniewagi nosiło miano przestępstwa obrazy, przy czym jego treść ujęta w art. $256 \S 1$ nie różniła się ani od późniejszego tekstu art. 181 § 1 k.k. z 1969 r., ani od obecnego tekstu art. $216 \S 1$ k.k. - z tym że zwrot „obraża” został zastapiony w 1969 r. wyrazem ,znieważa” - co jak podkreślano w doktrynie w meritum niczego nie zmieniało ${ }^{9}$. W porównaniu z treścią art. $181 \S 1$ k.k. z 1969 r. zwraca uwagę fakt, że przestępstwo zniewagi w obecnie obowiązującym Kodeksie karnym w podstawowej postaci (art. $216 \S 1$ k.k.) zagrożone jest łagodniejszą sankcją, a mianowicie grozi za nie jedynie

9 W. Wolter w: I. Andrejew, W. Świda, W. Wolter, Kodeks karny z komentarzem, Warszawa 1993, s. 529-530. 
kara nieizolacyjna, a mianowicie grzywna i ograniczenie wolności. Nieznana była także w Kodeksie karnym z 1969 r. kwalifikowana postać zniewagi, a mianowicie znieważenie za pomocą środków masowego komunikowania (odnośnie środków masowego komunikowania por. wyżej uwagi do art. 212 k.k.).

Dobrem chronionym przez treść art. 216 k.k. jest cześć człowieka, a ściślej jego godność osobista rozumiana jako wewnętrzny aspekt przynależny $\mathrm{czci}^{10}$. Art. 216 k.k. stoi na straży gwarantowanego treścią art. 47 Konstytucji prawa do czci i dobrego imienia ${ }^{11}$.

Przestępstwo zniewagi może godzić tylko w godność osobistą człowieka. Możliwe jest, że zniewaga dotyczy jednocześnie kilku osób, ale zawsze są to konkretne jednostki, co do których możliwa jest identyfikacja i indywidualizacja. Ustawodawca nie przewiduje możliwości znieważenia grupy jako zbiorowości osób nieoznaczonych indywidualnie. Sformułowanie zawarte $\mathrm{w}$ treści art. $216 \S 1$ nie pozwala na przyjęcie, iż przedmiotem zniewagi mogłaby być instytucja, osoba prawna, jednostka organizacyjna. Przedmiotem zniewagi może być każdy człowiek niezależnie od jego właściwości osobistych, a więc także nieletni, niemający zdolności do czynności prawnych; upośledzony umysłowo, niezależnie od tego czy jest ubezwłasnowolniony, czy też nie, byle był zdolny do świadomego odbioru zniesławiających treści. Nie można natomiast znieważyć osoby zmarłej, gdyż takowej osobie nie przysługują prawa osobiste. Samoistnym dobrem jest jednak kult pamięci po zmarłej osobie bliskiej, chociaż nie został on wymieniony wyraźnie w treści art. 23 k.c. ${ }^{12}$ W wyroku z dnia 11 kwietnia 1938 r. Sąd Najwyższy wskazał jeszcze na

10 B. Kunicka-Michalska w: B. Kunicka-Michalska, J. Wojciechowska, Przestępstwa przeciwko..., s. 308. Godnością człowieka jest subiektywne przekonanie o własnej wartości, subiektywne poczucie własnej wartości, przynależne każdemu człowiekowi i wynikające z faktu bycia człowiekiem (W. Kulesza, Zniesławienie i zniewaga..., s. 164).

11 J. Sobczak, Godność człowieka, w: Polityka zdrowotna a akcesja Rzeczpospolitej do Unii Europejskiej, red. T. Maksymiuk, J. Skrzypczak, Poznań 2006, s. 9 i n.; odnośnie pojęcia godności zob. wyżej uwagi wstępne do rozdziału XXVII tezy od 2 do 15 oraz uwagi do art. 212, Przedmiot ochrony, teza 1.

12 M. Pazdan w: Prawo cywilne. Czesść ogólna. System prawa prywatnego, t. I, red. M. Safjan, Warszawa 2007, s. 1141-1142. Por. także A. Szpunar, Ochrona prawna kultu osoby zmartej, Pal. 1978, nr 8, s. 29; S. Rudnicki, Prawo do grobu, Zagadnienia cywilistyczne, Kraków 1999, s. 37; J. S. Piątkowski, Ewolucja ochrony dóbr osobistych, w: Tendencje rozwoju prawa cywilnego: zbiór studiów, red. E. Łętowska, Wrocław 1983, s. 30 i n. 
gruncie k.k. z 1932 r., że warunkiem uznania ubliżenia pamięci zmarłego za zniewagę żyjącego bliskiego krewnego tego zmarłego jest ustalenie, że sprawca wyraził się w sposób ubliżający pamięci zmarłego bądź w obecności takowego bliskiego krewnego, bądź publicznie lub w zamiarze by jego słowa dotarły do krewnego oraz, że działa albo wprost w zamiarze dotknięcia żyjącego krewnego, albo przynajmniej w przeświadczeniu, że osoba ta wyrażenie jego odczuje jako zamach na jej osobistą godność i godził się na to ${ }^{13}$.

W znaczeniu potocznym ,zniewaga” to ,ubliżenie komuś słowem lub czynem, to ciężka obraza”; „znieważyć” to „ubliżyć komuś, zachować się względem kogoś w sposób obraźliwy, zelżyć kogoś”14. „Zniewaga” to „ubliżenie komuś słowem lub czynem, ciężka obraza, obelga, dyshonor" ${ }^{\prime 15}$. Zachowanie sprawcy przestępstwa z art. 216 k.k. polega na znieważeniu innej osoby. Ustawodawca bardzo ogólnie określa czynność sprawczą, nie wskazując bliżej sposobu zniesławienia. W doktrynie wskazuje się, że zniewagą są rozmaitego rodzaju zachowania, których wspólną cechą jest to, że wyrażają pogardę dla godności drugiego człowieka ${ }^{16}$. Znieważające zachowanie może przybrać formę słowną, kiedy sprawca posługuje się wulgaryzmami, słowami powszechnie uznanymi za obelżywe zarówno w formie ustnej, jak i pisemnej. Jak zauważono wyżej zniewagą mogą być słowa, które tylko w pewnym środowisku są uznawane za takowe. Określeniami takimi będą np. „konował” czy „rzeźnik” użyte w stosunku do lekarza; ,kauzyperda”, „papuga” w odniesieniu do adwokata; „,belfer” w stosunku do nauczyciela; ,biurokrata” na oznaczenie urzędnika; ,zupak” w odniesieniu do oficera lub podoficera; „klawisz” na oznaczenie strażnika więziennego; ,glina”, „blacharz”, „pies” w stosunku do funkcjonariusza policji. Słowami znieważającymi mogą być także takie, których prawdziwego znaczenia sprawca i ofiara nie znają, a które w określonym środowisku pojmowane są jako obelgi, np. „rusałka”, „skwarek”, „sufragan”. W okresie międzywojennym za zniewagę uznano nazwanie kogoś „galileuszem” stwierdzając, że dla bytu przestępstwa zniewagi wystarcza zamiar choćby ewentualny naruszenia godności oso-

13 Wyrok SN z dnia 11 kwietnia 1938 r., sygn. akt III K 2211/37, OSN P 1939, poz. 51 .

14 M. Szyczmak, Słownik języka polskiego, t. III, s. 1049.

15 S. Dubisz, Uniwersalny słownik, t. 4, s. 1056.

16 J. Raglewski w: Kodeks karny. Część szczególna. Komentarz, t. II, red. A. Zoll, Kraków 2006, s. 828. 
bistej lub nawet dotknięcie jego miłości własnej za pomocą wyrazów uważanych za przykre ${ }^{17}$. Najczesściej zniewagi to słowa powszechnie uznawane za obelżywe np. „gnój”, „,cham”, „świnia”, „krowa”, „klępa”, „zołza”, „ladacznica”, „latawica”, „bydlak”, „łajdak”, „łobuz”, „kmiot”, „,bamber”, „menel”, „wsiór”, „ścierwo”, „padalec”, ,żmija”, „k...”, „,ch...”, „p...”. Za obelżywe mogą być też uznane słowa o treści obojętnej jak np. „małpa”, „księży pachołek”, albo wiążące się z określonym światopoglądem czy ideologia przypisywanym przez sprawcę pokrzywdzonemu np. „faszysta”, „komunista”, „,dewot”. Niektóre zniewagi dodatkowo mogą wyczerpywać znamiona innych przestępstw wtedy, gdy nacechowane są treściami rasistowskimi, antysemickimi lub mającymi napiętnować kogoś z racji przynależności do określonego narodu. Taki charakter mają określenia: „,asfalt”, „,negro”, „czarnuch”, a nawet „murzyn” czy „żydek”, „kacap”, „szwab”, „pepiczek”. Część zniewag zdaje się sugerować upośledzenie umysłowe pokrzywdzonego. Należą do nich takie sformułowania jak: „debil”, „idiota”, „wariat”, „głupek”, „półgłówek”, „baran”, „bałwan”. Obelgą mogą być słowa uznawane za takowe w określonych środowiskach, gwarowe: „luntrus”, „cwel”, „łapserdak”, „ćwok”. Niektóre ze zniewag rozumiane są zasadniczo w określonym środowisku np. „sędzia kalosz” czy „padurano” na oznaczenie niesprawiedliwego arbitra piłkarskiego. Niektóre sformułowania obelżywe to kakofemizmy zwane również dysfeminizmami, polegające na nazywaniu kogoś nazwą pogardliwą, np. mianowanie przeciwnika politycznego ,awanturnikiem politycznym". Używający kakofemizmów najczęściej może jednocześnie wyczerpać znamiona zniesławienia i zniewagi.

Sąd Najwyższy jeszcze przed wejściem k.k. z 1932 r. stwierdził, że okrzyk „hańba”, „hańba mu”, zawiera obwinienie o czyny hańbiące, niemoralne i wyraża wzgardę stanowiąc zniewagę ${ }^{18}$. W orzecznictwie $\mathrm{z}$ tego okresu stwierdzono, że obelgi nie muszą polegać na użyciu słów obelżywych ogólnie znanych, ale mogą być nimi pogróżki, słowa wyszydzające lub wyśmiewające drugiego i generalnie wszelkie słowa mogące kogoś w oczach innych ludzi poniżyć i dotknąć go na czci, choćby same nie były wyrazami obelżywymi. Zauważono przy tym, że jako obelgi należy uważać takie ubliżające traktowanie kogoś w obecności innych osób, że

17 Wyrok SN z dnia 25 października 1937 r., sygn. akt I K 910/37, OSP 1938, poz. 394.

18 Orzeczenie SN z dnia 3 kwietnia 1928 r., sygn. akt Kr 137/28, RPiE 1928, z. 4, s. 1011 . 
stanowi to poniżenie go w oczach innych i wywołać może u tych osób mniemanie, że obrażony swym postępowaniem lub rysami charakteru zasługuje na takie uwłaczające jego czci traktowanie ${ }^{19}$. Rozważając ciekawy problem czy znieważeniem jest zwracanie się do kogoś z pominięciem formy „pan”, „pani”, lecz przez „ty” Sąd Najwyższy w okresie międzywojennym, jeszcze przed wejściem w życie k.k. z 1932 r. kilkakrotnie stwierdził, że tego rodzaju formy są oznaką nieposzanowania, które nie wyczerpują znamion obelgi w niektórych sytuacjach, kiedy sprawca zwraca się do osoby starszej, zwierzchnika, pracodawcy moga być uznane za obelgę słowną ${ }^{20}$. Za zniewagę uznano przy tym zarówno wyproszenie kogoś z pomieszczenia słowem „won”, jak i przez użycie zwrotu „czy pani pójdzie od jasnej cholery” ${ }^{\text {21 }}$.

Zachowanie sprawcy może przybrać formę także gestu np. pokazanie pokrzywdzonemu środkowego palca jednej z rąk, znaczącego pukania się w czoło, wypięcie pośladków, pokazanie komuś języka. Niektóre gesty znieważające nie są znane w Polsce, lecz powszechne w innych krajach. Taki charakter ma pokazanie w niektórych regionach Anglii palca wskazującego i środkowego w układzie równoległym do powierzchni ziemi.

W judykaturze jeszcze na tle art. 256 k.k. z 1932 r. wywiedziono, że szereg obelg wypowiedzianych w stosunku do określonej osoby w toku jednego zdarzenia, stanowi jedną obrazę. Natomiast obelgi identyczne co do treści, lecz powtarzane w różnym czasie, stanowią odrębne czyny przestępne, gdy dotyczą różnych zdarzeń, chyba, że sąd z uwagi na jednolitość zamiaru przestępnego i jednolitość naruszonego dobra uzna je za jeden czyn ciagły. Dodano także, że obelgi w toku jednego zatargu, skierowane do kilku osób stanowią jeden czyn, jeżeli wszystkie osoby zelżono jednym zwrotem, np. „złodzieje”, albo też szereg czynów, jeżeli w stosunku do każdej osób użyto innych zwrotów obelżywych ${ }^{22}$.

19 Orzeczenie z dnia 27 stycznia 1939 r., sygn. akt II K 316/30, GS 1930, z. 6, s. 405 .

20 Orzeczenia SN z dnia 12 maja 1932 r., sygn. akt II 3 K 323/32, GS 1932, z. 7-8, s. 499; z dnia 20 stycznia 1926 r., sygn. akt II K 2066/1925, OSN K 1926, poz. 19.

21 Wyrok SN z dnia 3 lutego 1931 r., sygn. akt II 4 K 16/31, RPiE 1931, z. 4, s. 1919; orzeczenie Najwyższego Sądu Wojskowego z dnia 12 sierpnia 1936 r., sygn. akt R 239/46 RPiE 1937, z. 2, s. 411.

22 Wyrok SN z dnia 27 września 1935 r., sygn. akt III K 801/35, OSN K 1932, nr 60, poz. 571 . 
Przyznanie faktu obelgi z oświadczeniem wypowiadającego słowa obelżywe, że słów tych nie cofa, jak zauważał Sąd Najwyższy jeszcze przed wejściem k.k. z 1932 r., należy oceniać jako nowy, odrębny czyn przestępny $^{23}$.

Nie każde zachowanie naruszające standardy kultury i obyczajów może być traktowane jako znieważające. „Istotą znieważenia jest okazanie pogardy, która w głębi wyraża ujemny stosunek do wartości, jaką reprezentuje sobą człowiek aniżeli lekceważenie". Braku ogłady nie można traktować jako zniewagi. Jak podkreśla W. Kulesza „między zachowaniem, które oceniamy jako niestosowne, niegrzeczne czy nawet lekceważące a przestępstwem zniewagi istnieje poważna różnica w ładunku ujemnej treści społecznej, która sprawia, że brak okazania szacunku społecznie niewłaściwy nie będzie jednak traktowany jako równoznaczny z przestępnym wyrażeniem pogardy wobec drugiego człowieka". Na tym tle rozważany bywa kazus odmowy podania ręki osobie, która w określonym środowisku podejrzewano, że jest płatnym informatorem urzędu bezpieczeństwa uznając, że czyn taki ma charakter zniesławienia a nie zniewagi (obrazy) $)^{24}$.

Dla realizacji znamion czynu zabronionego nie jest istotne czy według odczuć osoby, do której kierowane było dane zachowanie została naruszona nim jej godność osobista. Nazwanie Polaka „Polakiem” nie zawiera w sobie znamion zniesławienia, podobnie jak Żyda „Żydem” czy Niemca „Niemcem”, natomiast nazwanie kogoś ,polaczkiem”, „niemiaszkiem”, „żydkiem” nawet, jeżeli tym określeniom nie towarzyszą przymiotniki uwłaczające czci takie jak „obmierzły”, „podstępny”, ,zapluty”, „wszawy" itd. wyczerpuje znamiona zniesławienia z racji pejoratywnej, pogardliwej treści. W literaturze podnosi się, że zniewagę mogą stanowić jedynie takie zachowania, które są powszechnie uznane za obelżywe. Jeżeli zachowanie sprawcy nie zawiera społecznie uznanych cech zniewagi to nie stanowi przestępstwa, nawet jeśli osoba, do której skierowane było zachowanie sprawcy subiektywnie poczuła się nim obrażona ${ }^{25}$. W doktrynie podkreśla się, że przy ocenie czy zachowanie sprawcy ma charakter

23 Orzeczenie SN z dnia 13 grudnia 1931 r., sygn. akt II 3 K 981/31, GS 1932, z. 2, s. 124. Pogląd taki został powtórzony w wyroku z dnia 14 września $1933 \mathrm{r}$. sygn. akt 3 K 615/33, RPiE 1934, z. 2, s. 474.

${ }_{24}$ W. Kulesza, Zniestawienie i zniewaga..., s. 174.

25 J. Wojciechowski w: A. Wąsek, R. Zawłocki, Kodeks karny. Część szczególna, t. I: Komentarz do artykułów 117-221, wyd. 4, Warszawa 2010, s. 1347. 
znieważający decydujące znaczenie mają normy obyczajowe. Jako przykład wskazuje się wznoszenie podczas zawodów sportowych okrzyku „sędzia kalosz” czy nawet bardziej obelżywych okrzyków pod adresem arbitra zawodów czy konkretnego sportowca, podnosząc, że formułowanie takich okrzyków jest zwyczajowo przyjęte na niektórych zawodach sportowych $^{26}$. Z poglądami tymi trudno się zgodzić zważywszy, że zamiarem sprawców wznoszących tego typu okrzyki jest właśnie znieważenie arbitra czy sportowca, któremu nie powiodła się rywalizacja. W żaden sposób nie można przyjąć, że są miejsca i okoliczności, w których bezkarnie można znieważać drugiego człowieka nawet, jeżeli tego rodzaju zniewagi mają miejsce często. Podkreślić należy, że przy zniewagach - czego zwykle nie dostrzega literatura, a nawet niedostatecznie akcentuje judykatura - istotne znacznie ma sposób wypowiedzi, tembr głosu, właściwa intonacja. Zdarza się, że niektóre określenia mogą zabrzmieć wręcz pieszczotliwie a inne, wydawałoby się o mniejszym ładunku pejoratywności, odebrane będą jako wysoce znieważające.

W literaturze podnosi się, że w sytuacji, w której autor wypowiedzi błędnie sądzi, iż zawiera ona znieważającą treść, to może odpowiadać za usiłowanie nieudolne przestępstwa zniewagi (art. $13 \S 2 \mathrm{w}$ związku $\mathrm{z}$ art. 216 k.k. $)^{27}$. Z poglądem tym nie do końca można się zgodzić. Jest on uzasadniony w sytuacji, gdy adresat wypowiedzi zna właściwe znaczenie słowa „sufragan” i nie traktuje go jako zniewagi. Jeśli jednak obie strony, sprawca i pokrzywdzony, znają treść przypisywaną temu określeniu w pewnym środowisku, w którym jest ono traktowane jako wysoce pejoratywne, wówczas niewątpliwie zaistnieje przestępstwo zniewagi. Generalnie jednak możliwe jest znieważenie każdego człowieka bez względu na to, czy jest on zdolny do percepcji zniewagi. Zgodzić się należy z tezą J. Wojciechowskiego, że można znieważyć dziecko nawet, jeżeli ono nie rozumie użytych wobec niego słów i nie traktuje ich jako zniewagi. Przykładem może być nazwanie małej dziewczynki przez matkę jej koleżanki z piaskownicy „małą k...”. Trafna jest więc konstatacja, że w takiej sytuacji w pełni dopuszczalne jest oskarżenie o znieważenie dziecka wytoczone przez rodziców czy opiekunów zastępujących dziecko w prawach pokrzywdzonego. Tak więc ochrona prawno-karna dotyczy także osób, które z różnych względów: $\mathrm{z}$ racji wieku, chrobry psychicznej, nie

26 J. Wojciechowski w: A. Wąsek, R. Zawłocki, Kodeks karny..., s. 1348; J. Raglewski w: Kodeks karny, t. II, red. A. Zoll, s. 828-829.

27 J. Raglewski w: Kodeks karny, t. II, red. A. Zoll, s. 829. 
są w stanie rozpoznać znieważającego charakteru działania sprawcy ${ }^{28}$. Możliwe jest znieważenie osoby psychicznie chorej, która nie rozumie treści zniewagi. Przestępstwo zniewagi nie ma charakteru skutkowego, a więc to czy ktoś się poczuje poniżony nie należy do znamion tego przestępstwa. Poczucie pokrzywdzenia ma jedynie znaczenie w aspekcie decyzji pokrzywdzonego o wniesieniu przeciwko sprawcy zniewagi aktu oskarżenia $^{29}$. Tak więc $\mathrm{z}$ reguły nie będzie mowy o znieważeniu jeżeli pokrzywdzony nie poczuje się dotknięty zachowaniem sprawcy i nie odbierze tego zachowania jako zniewagi. Można znieważyć osobę śpiąca, oczywiście w sytuacji, gdy znieważający czyni to publicznie ${ }^{30}$.

Znieważenie może nastąpić wyłącznie w formie działania przez wypowiadanie obraźliwych słów, wykonywanie obelżywych gestów. Nie wystarczy zachowanie bierne lub ignorowanie jakiejś osoby ${ }^{31}$. W doktrynie podnosi się, że zaniechanie nie jest tożsame z brakiem działania, lecz zaistnieje wówczas, gdy sprawca nie podejmuje nakazanego przez obowiązujący system normatywny działania. Podkreśla się jednak, że w praktyce istnieje problem w odniesieniu do czynu z art. 216 k.k., ze wskazaniem podstawy normatywnej takiego obowiązku ${ }^{32}$. Nie można stawiać znaku równości między zniewagą a brakiem taktu. Nie jest więc zniewagą ignorowanie innej osoby ${ }^{33}$.

W literaturze podnosi się, że w art. 216 k.k. można wyróżnić trzy odmiany modalne typu podstawowego, a mianowicie: znieważenie jakiejś osoby w jej obecności, zarówno słowem, jak i gestem; zniewagę dokonaną pod nieobecność osoby znieważonej, lecz publicznie; zniewagę dokonaną pod nieobecność osoby znieważonej, niepublicznie, lecz w zamiarze,

28 J. Wojciechowski w: A. Wąsek, R. Zawłocki, Kodeks karny..., s. 1348; W. Kulesza, Zniesławienie i zniewaga..., s. 165-169.

29 P. Hofmański, J. Satko, Przestepstwa przeciwko czci..., s. 46-47; W. Kulesza, Zniesławienie $i$ zniewaga..., s. 167; wyrok Najwyższego Sądu Wojskowego z dnia 3 lutego 1938 r., sygn. akt KKN 401/37, WPP 1938, z. 3, s. 109.

30 J. Raglewski w: Kodeks karny, t. II, red. A. Zoll, s. 831.

31 A. Zoll w: Kodeks karny..., red. A. Zoll, s. 665; B. Kunicka-Michalska w: B. Kunicka-Michalska, J. Wojciechowska, Przestępstwa przeciwko wolności..., s. 317; P. Hofmański, J. Satko, Przestępstwa przeciwko czci..., s. 48; J. Wojciechowski w: A. Wąsek, R. Zawłocki, Kodeks karny..., s. 1124-1125; A. Marek, Kodeks karny..., s. 480; odmiennie R. Góral, Kodeks karny..., s. 342; M. Surkont, Zniestawienie i znieważenie, s. 175.

32 W. Kulesza, Zniestawienie i zniewaga..., s. 173; A. Marek, Kodeks karny. Komentarz, 5. wydanie, Warszawa 2010, s. 486-487.

33 J. Raglewski w: Kodeks karny, t. II, red. A. Zoll, s. 1348-1349. 
aby dotarła ona do tej osoby - „zniewaga zaoczna”34. Tak więc sprawca znieważenia może dokonać go w obecności osoby znieważonej; pod jej nieobecność, ale publicznie; pod nieobecność pokrzywdzonego, niepublicznie, ale z zamiarem, aby zniewaga dotknęła osobę znieważaną. Znieważenie najczęściej jednak czynione jest wprost i kierowane bezpośrednio do osoby znieważonej, w kontakcie bezpośrednim, w rozmowie telefonicznej bądź listownie. W ostatnich latach nader częstym zjawiskiem jest znieważanie innych osób słowami powszechnie uznanymi za obelżywe, na publicznie dostępnych forach internetowych. Od tej sytuacji należy odróżnić zniewagi w postach, przekazach mailowych kierowanych do określonej osoby lub do grup osób, imiennie oznaczonych, w których to przekazach znieważane są inne jednostki. Takie przekazy mają charakter korespondencji i nie spełniają znamienia publiczności. Możliwe jest jednak znieważanie kogoś pośrednio przez wypowiedź lub gest adresowane do pokrzywdzonego. Znieważenie będzie karalne wtedy, gdy zniewaga została dokonana w obecności osoby znieważonej bądź publicznie, ale w taki sposób, aby mogła być odebrana przez bliżej nieokreślony kragg osób.

Pojęcie „obecności” osoby znieważonej należy rozumieć w ten sposób, że pokrzywdzony jest bezpośrednim odbiorcą informacji znieważającej. Pod terminem „obecność” należy rozumieć znajdowanie się znieważanego w miejscu, w którym następuje znieważenie. W znaczeniu potocznym „obecnie” to w „bieżącej chwili, teraz”; „obecny” to ktoś „osobiście przy czymś będący, znajdujący się gdzieś w danej chwili”; „obecność" to „znajdowanie się gdzieś, przebywanie czasowe, bytność”35. Znieważenie w obecności należy rozumieć w ten sposób, że pokrzywdzony znajduje się fizycznie w tym miejscu, w którym formułowane są pod jego adresem treści znieważające. Znieważeniem w obecności jest także znieważenie w rozmowie telefonicznej, w której znieważający i znieważany znajdują się w miejscach nader od siebie odległych, także drogą mailową czy listownie. Oczywiście konieczne jest ustalenie, że znieważające wypowiedzi dotarły do pokrzywdzonego ${ }^{36}$. Znieważenie w nieobecności pokrzywdzo-

34 J. Waszczyński w: System prawa karnego, t. IV, cz. 2, s. 110; B. Kunicka-Michalska w: B. Kunicka-Michalska, J. Wojciechowska, Przestęstwa przeciwko..., s. $319-320$.

35 Słownik języka polskiego, t. II, red. M. Szymczak, s. 407.

36 O. Górniok w: O. Górniok i inni, Kodeks karny. Komentarz, Gdańsk 2002/2003, s. 1034-1035. 
nego, ale w zamiarze, aby zniewaga do niego dotarła ma miejsce w sytuacji, kiedy znieważające treści nie mogą dotrzeć do znieważanego w tym samym czasie w jakim zostały wyrażone, ale zamiarem sprawcy jest to, aby do niego dotarły, aby zostały mu powtórzone bądź przetłumaczone, jeśli wypowiedź została sformułowana w języku nieznanym pokrzywdzonemu ${ }^{37}$. Przestępstwo zniewagi dokonane w rozpowszechnionym piśmie lub druku ma charakter publiczny, w związku z tym nie jest konieczne, aby pismo lub druk dotarły do pokrzywdzonego.

Zamiar znieważenia musi jednoznacznie wynikać z zachowania sprawcy lub z okoliczności, w których doszło do wyrażenia znieważających treści. Nie jest wystarczające stwierdzenie, że wypowiedziana w nieobecności pokrzywdzonego zniewaga do niego dotarła ${ }^{38}$. W przypadku zniewagi zaocznej, czyli dokonanej pod nieobecność osoby znieważonej i niepublicznie, lecz w zamiarze, aby dotarła ona do pokrzywdzonego, znamiona przestępstwa $\mathrm{z}$ art. 216 k.k. zostaną wyczerpane nawet jeśli „osoba pośrednicząca” nie przekazała pokrzywdzonemu treści zniewagi ${ }^{39}$. Sprawca znieważenia nie będzie odpowiadał jednak za zniewagę w sytuacji, w której niepublicznie sformułował znieważającą treść, ale bez zamiaru, aby dotarła ona do osoby znieważanej lub wręcz w zamiarze, aby znieważany nigdy się o tym nie dowiedział - a mimo to wbrew woli i zamiarowi sprawcy takowa wypowiedź została pokrzywdzonemu przekazana ${ }^{40}$.

Nie jest zniewagą wyrażenie obraźliwych treści pod adresem pokrzywdzonego, przy jego nieobecności, niepublicznie oraz w sytuacji, kiedy znieważający nie ma zamiaru, aby zniewaga dotarła do pokrzywdzonego, chociaż do niego dociera wbrew woli sprawcy ${ }^{41}$. Dyskusyjne bywa w praktyce czy zniewagą może być określenie, którego znieważający nie rozumie np. wypowiedziane w obcym języku lub z użyciem wyrażeń, których pokrzywdzony nie zna. Decydować powinien jednak zamiar sprawcy i fakt, że zniewaga pokrzywdzonego została odebrana przez osoby, które treść wypowiedzi odbierają jako zniewagę.

Sprawca zniewagi będzie ponosił odpowiedzialność niezależnie od tego czy osoba znieważona pełni funkcję publiczną, czy też nie. W literaturze zauważa się, że zniewaga nie jest formą krytyki, a wynika przeważnie

37 J. Bafia, K. Mioduski, M. Siewierski, Kodeks karny..., t. II, s. 167.

38 O. Górniok w: O. Górniok i inni, Kodeks karny. Komentarz..., s. 1035.

39 P. Hofmański, J. Satko, Przestępstwa przeciwko czci..., s. 49.

40 J. Raglewski, w: Kodeks karny. Część szczególna..., t. II, red. A. Zoll, s. 833.

41 J. Wojciechowski w: A. Wąsek, R. Zawłocki, Kodeks karny..., s. 1349-1350. 
z chęci dokuczenia pokrzywdzonemu ${ }^{42}$. Zniewaga nie jest też formą realizacji debaty publicznej, aczkolwiek przyznać należy, że w orzecznictwie Trybunału w Strasburgu jako dopuszczalne wypowiedzi uznano znieważające określenia, nazywające wypowiedzi Kanclerza Austrii za najbardziej nikczemny oportunizm oraz za niemoralne i niegodne ${ }^{43}$, czy nazwanie jednego z austriackich działaczy politycznych J. Haidera mianem ,idioty "44, określenie ministra spraw zagranicznych mianem „gruboskórnego" "45, wreszcie nazwanie strażników miejskich „ignorantami”, „głupkami” i „ćwokami”46.

Zniewaga popełniona przy użyciu środków masowego komunikowania powoduje surowszą odpowiedzialność (w kwestii pojęcia środków komunikowania zob. wyżej uwagi do art. 212 k.k., Uwagi ogólne, teza 11; Kwalifikowane typy zniesławienia, tezy od 1 do 4, 6, 8). W tym miejscu przypomnieć należy, że środkiem masowego komunikowania będzie prasa tzw. drukowana w formie papierowej i internetowej, przekaz radiowy, telefoniczny i internetowy, jednak z wyjątkiem korespondencji. Wypada zauważyć, iż właśnie w przekazach internetowych nader często osoby zamieszczające tam swoje uwagi dopuszczają się zniesławienia ${ }^{47}$.

Publiczny charakter czynu, o jakim mowa w treści art. $216 \S 1$ k.k. oznacza, że czyn został popełniony w taki sposób, że może być dostrzeżony przez nieokreśloną z góry liczbę osób. Działanie publiczne, które stanowi jedno ze znamion czynu z art. 216 k.k., jest znamieniem także wielu innych przestępstw, np. z art. 133, 135 § 2, 136 § 3 i 4, 137, 196, 202, $226 \S 3$, 255, 256, 257 k.k. „Publicznego działania” nie wolno jednak mylić z „miejscem publicznym” zważywszy, że działanie w miejscu publicznym nie zawsze jest działaniem publicznym, choć najczęściej tak jest. „Działanie publiczne” nie musi tak samo oznaczać działania w miejscu publicznym. „Publiczność działania” ma miejsce wtedy, kiedy zniewaga kierowana do konkretnej osoby mogła być odebrana przez szeroki,

42 Ibidem, s. 1350

43 Sprawa Lingens przeciwko Austrii, skarga nr 9815/82. Za dopuszczalne uznano także określenia działacza politycznego mianem „faszysta” (Feldek przeciwko Słowacji, skarga nr 29032/95).

44 Oberschlick przeciwko Austrii, skarga nr 20834/92.

45 Dichand przeciwko Austrii, skarga nr 2971/95.

46 Janowski przeciwko Polsce, skarga nr 25716/94.

47 J. Sobczak, Zniestawienie w Internecie, w: Oblicza Internetu. Opus Universale. Kulturowe, edukacyjne i technologiczne przestrzenie Internetu, red. M. Sokołowski, Elblag 2008, s. 28-53. 
bliżej nieokreślony kragg osób. Sąd Najwyższy w wyroku z dnia 4 lutego 2003 r. ${ }^{48}$, odnoszącym się jednak do art. $256 \S 1$ k.k. z 1932 r. stwierdził, że o „publiczności działania” można mówić jedynie wówczas, gdyby mogło być ono dostrzegane przez nieokreśloną ani ilościowo, ani indywidualnie liczbę osób. Podobny pogląd sformułował wcześniej Sąd Najwyższy jeszcze w okresie międzywojennym, w wyroku z dnia 10 lutego 1937 r., stwierdzając, że zagadnienie czy zniewaga została uczyniona publicznie czy też nie, zależne jest od rozstrzygnięcia czy w danej chwili zachodziła możliwość usłyszenia zniewagi przez nieokreśloną ani ilościowo, ani indywidualnie liczbę osób ${ }^{49}$.

Przestępstwo zniewagi należy do kategorii przestępstw powszechnych, a sprawcą tego przestępstwa może być każda osoba. W literaturze podkreśla się, że sprawcą przestępstwa z art. 216 k.k. może być jedynie osoba dorosła w rozumieniu prawa karnego, a więc może je popełnić jedynie człowiek po ukończeniu siedemnastego roku życia. Czyn z art. 216 k.k. nie należy do przestępstw wymienionych w art. $10 \S 2$ k.k. a więc do tych, za które w określonej w tym przepisie sytuacji mogą odpowiadać karnie nieletni po ukończeniu piętnastego roku życia ${ }^{50}$.

Przestępstwo zniewagi zwykle dokonywane jest przez jednego sprawcę (w formie sprawstwa pojedynczego). Może być popełnione w formie współsprawstwa, kiedy dwie lub więcej osób dopuszcza się zniewagi pod adresem pokrzywdzonego np. w wysłanym do niego wspólnym liście. Możliwe jest także popełnienie przestępstwa zniewagi w formie sprawstwa kierowniczego, kiedy ktoś zainspiruje innych do znieważania pokrzywdzonego, kierując ich postępowaniem. Oczywiście możliwe jest także podżeganie i pomocnictwo do przestępstwa zniewagi. Podżeganie sprowadzać się będzie do nakłaniania innej osoby do znieważenia pokrzywdzonego, zachęcanie jej do tego. W praktyce rozróżnienie podżegania od sprawstwa kierowniczego może okazać się trudne do rozstrzygnięcia. Niezbędne będzie każdorazowo zbadanie na ile sprawca miał możność kontrolowania działań osoby bezpośrednio znieważającej. Pomocnictwo zasadzać się będzie na dostarczaniu informacji pomocnych do znieważania, albo narzędzi ku temu. J. Wojciechowski wskazuje, że pomocnic-

48 IV KK 79/02; LEX, nr 75450.

49 Wyrok SN z dnia 10 lutego 1937 r., sygn. akt II K 1554/36, OSN K 1937, nr 8, poz. 225.

50 J. Wojciechowski w: A. Wąsek, R. Zawłocki, Kodeks karny..., s. 1350. 
twem może być dostarczenie sprawcy farby w celu sporządzenia napisu na murze o treści znieważającej ${ }^{51}$.

Przestępstwo zniewagi jest przestępstwem umyślnym. Może dopuścić się go tylko ten, kto zdaje sobie sprawę z faktu, że jego zachowanie wyczerpuje znamiona przestępstwa zniewagi. Sprawca, który dopuszcza się zniewagi używając słów obelżywych w językach obcych, których znaczenia nie zna i nie rozumie lub przypisuje im inną treść bądź używając określeń, które tylko w określonym środowisku mają charakter znieważający nie wyczerpuje znamion przestępstwa $\mathrm{z}$ art. 216 k.k. W judykaturze na tle art. 256 k.k. z 1932 r., w okresie międzywojennym wyrażono jednak pogląd, że odezwanie się, które obiektywnie zdolne jest poniżyć godność osobistą innej osoby nie traci cech zniewagi z tego tylko powodu, że zostało wypowiedziane w języku dla tej osoby niezrozumiałym, jeżeli sprawca działa chociażby w ewentualnym zamiarze znieważenia ${ }^{52}$. Dodać należy, że dość częstym zjawiskiem jest, iż pokrzywdzony nie zna wprawdzie języka, w którym sformułowano obelgi, ale treść obelg mimo to rozumie $\mathrm{z}$ uwagi na upowszechnienie ich znaczenia przez literaturę, film lub fakt, że są one dość często w użyciu. Dotyczy to zwłaszcza takich języków jak rosyjski, niemiecki, angielski, francuski, a nawet włoski.

Znieważenie może być dokonane w pierwszym rzędzie w zamiarze bezpośrednim. W literaturze podkreśla się, iż możliwe jest także znieważenie w zamiarze ewentualnym, w sytuacji, gdy sprawca nie chce wprost znieważyć innej osoby, ale godzi się z tym, że swoim zachowaniem ją znieważył. Wykluczone wydaje się natomiast znieważenie z zamiarem ewentualnym w sytuacji, gdy sprawca nie działa publicznie, ani w obecności pokrzywdzonego, a jedynie w zamiarze, aby zniewaga do niego dotarła. Pogląd taki na gruncie art. 181 k.k. z 1969 r., odpowiadającego swą treścią art. 216 k.k., wielokrotnie formułowano w doktrynie ${ }^{53}$. W judykaturze okresu międzywojennego, na tle art. 256 k.k. z 1932 r., ukształtował się pogląd, w myśl którego „obraza jest występkiem umyślnym [...] nie

51 J. Wojciechowski, Przestępstwa przeciwko czci i nietykalności cielesnej, Warszawa 2000, s. 52.

52 Wyrok SN z dnia 4 marca 1937 r., sygn. akt III K 2394/36, OSN K 1937, nr 9, poz. 260.

${ }^{53}$ A. Banach, Ochrona czci i godności osobistej w Kodeksie karnym polskim, Kraków 1950, s. 119; J. Bafia, K. Mioduski, M. Siewierski, Kodeks karny. Komentarz, wyd. 2, Warszawa 1987, t. 2, s. 459; O. Górniok, w: O. Górniok i inni, Kodeks karny. Komentarz, Gdańsk 2002-2003, s. 1032-1033. 
jest wymagany zamiar znieważenia [...] wystarcza świadomość obrazy godności innej osoby. Jeżeli sprawca świadomość tę posiada, to obojętne jest czy chciał wręcz tę godność osobistą innej osoby poniżyć, czy tylko przewidywał to następstwo tych słów i na nie się godził" ${ }^{54}$. M. Siewierski komentując treść art. 256 k.k. z 1932 r. wyraził pogląd, że obraza jest przestępstwem umyślnym, a sprawca winien wiedzieć, że swymi słowami lub swoim zachowaniem poniża godność osobistą pokrzywdzonego, chcieć tego lub na to się godzić. Nie jest jednak konieczne, aby sprawca chciał poniżyć godność osobistą osoby (tzw. animus iniuriandi), wystarcza jeżeli to następstwo swoich słów przewidywał i na nie się godził ${ }^{55}$. W. Wolter na gruncie art. 181 k.k. z 1969 r., będącego odpowiednikiem art. 216 k.k. zauważył, że zniewaga jest przestępstwem umyślnym, które $\mathrm{z}$ reguły będzie popełniane działaniem z zamiarem bezpośrednim, przy czym sprawca musi zdawać sobie sprawę z ubliżającego charakteru swego zachowania ${ }^{56}$.

W literaturze powstały wątpliwości czy zamiar ewentualny wystarczy dla przypisania zniewagi w typie modalnym, polegającym na uzewnętrznieniu obraźliwych treści, pod nieobecność pokrzywdzonego, ale w zamiarze, aby ta zniewaga mimo wszystko do niego dotarła. Według J. Wojciechowskiego niezbędnym jest, aby sprawca chciał, aby zniewaga dotarła do osoby, której dotyczy ${ }^{57}$. Odmiennie A. Zoll podkreślający, że w takiej sytuacji „wystarczy zamiar wynikowy"58. To ostatnie stanowisko podziela P. Hofmański, wskazując że ustawa nie wymaga działania „W celu” lecz mówi o „zamiarze” by zniewaga dotarła do pokrzywdzonego. Tak więc zdaniem P. Hofmańskiego „możliwe i karalne jest znieważenie innej osoby pod jej nieobecność, ale ze świadomością, że zniewaga dotrze do tej osoby jeżeli tylko sprawca się na to godzi"59.

Przestępstwo zniewagi jest przestępstwem formalnym i bezskutkowym $^{60}$. Według J. Raglewskiego przestępstwo zniewagi jest przestęp-

54 L. Peiper, Komentarz do kodeksu karnego, Kraków 1936, s. 539.

55 M. Siewierski, Kodeks karny..., s. 342.

56 W. Wolter, w: I. Andrejew, W. Świda, W. Wolter, Kodeks karny..., s. 531.

57 J. Wojciechowski w: A. Wąsek, R. Zawłocki, Kodeks karny..., s. 1350; także tenże, Przestępstwa przeciwko czci..., s. 57.

58 A. Zoll w: Kodeks..., s. 668.

59 P. Hofmański w: P. Hofmański, J. Satko, Przestępstwa przeciwko czci..., s. 50.

60 W. Kulesza, Zniestawienie i zniewaga, s. 167; A. Zoll w: Kodeks karny..., s. 66; P. Hofmański w: P. Hofmański, J. Satko, Przestępstwa przeciwko czci..., s. 46; J. Wojciechowski w: A. Wąsek, R. Zawłocki, Kodeks karny..., s. 1351; A. Marek, 
stwem formalnym, dokonanym w momencie wykonania przez sprawcę działania znieważającego, przy czym nie jest wymagane zaistnienie jakiegokolwiek skutku. Nie jest konieczne, aby pokrzywdzony odczuł zachowanie sprawcy jako naruszające poczucie wartości, jako ujmę dla swojej godności ${ }^{61}$. Odmiennie M. Surkont i O. Górniok, według których przestępstwo z art. 216 k.k. ma charakter materialny ${ }^{62}$.

Nie jest konieczne, aby zniewaga dotarła do pokrzywdzonego, ważny jest natomiast zamiar sprawcy, jego chęć aby zniewaga dotarła do pokrzywdzonego bądź wprost, bądź w jakikolwiek inny sposób. W sytuacji, gdy sprawca przestępstwa z art. 216 k.k. dopuści się zniewagi w nieobecności pokrzywdzonego, przestępstwo jest dokonane niezależnie od tego czy „osoba pośrednicząca” przekaże zniewagę osobie, która została nią dotknięta, czy też nie ${ }^{63}$.

Typem kwalifikowanym zniewagi jest zniewaga dokonana za pośrednictwem środków masowego komunikowania. Ratio legis takowej konstrukcji jest dość oczywiste, gdyż zniewaga dokonana za pośrednictwem środków masowego komunikowania ma szerszy zasięg, większy obszar rażenia.

W art. $216 \S 3$ k.k. przewidziano możliwość odstąpienia od wymiaru kary w przypadku prowokacji i retorsji, czyli wtedy, gdy zniewagę wywołało wyzywające zachowanie się pokrzywdzonego (prowokacja), albo jeżeli pokrzywdzony odpowiedział naruszeniem nietykalności cielesnej lub zniewagą wzajemną (retorsja). W znaczeniu potocznym ,prowokacja” to „podstępne działania, mające na celu nakłonienie kogoś do określonego postępowania, zwykle zgubnego w skutkach dla tej osoby i osób z nią związanych”. „Prowokować” to „podżegać do czegoś w ukrytych zamiarach, starać się wywołać u kogoś określoną reakcję; pobudzać do określonych działań na korzyść prowokatora"64. Prowokacja zaistnieje wówczas, gdy zniewagę spowoduje wyzywające zachowanie znieważonego. W znaczeniu potocznym „retorsja” to „postępowanie będące

Kodeks karny..., s. 487; B. Kunicka-Michalska w: B. Kunicka-Michalska, J. Wojciechowska, Przestępstwa przeciwko wolności..., s. 314.

${ }_{61}$ J. Raglewski, w: Kodeks karny..., red. A. Zoll, s. 834.

${ }_{22}$ M. Surkont, Problem skutkowego charakteru zniestawienia i znieważenia, Pal. 1978, z. 4, s. 21-22; O. Górniok, w: O. Górniok i inni, Kodeks karny..., s. 1034.

${ }^{63}$ P. Hofmański, J. Satko, Przestęstwa przeciwko czci..., s. 49.

${ }^{64}$ M. Szymczak, Stownik jezzka polskiego, t. II, s. 946; S. Dubisz, Uniwersalny stownik języka polskiego, t. III, s. 599-600. 
odpowiedzią na czyjeś działanie" ${ }^{95}$. Retorsja dojdzie do skutku, gdy sprawca odpowie wzajemną zniewagą lub naruszeniem nietykalności cielesnej. Prowokacja i retorsja nie uchylają bezprawności czynu i nie są kontratypami. Zaistnienie ich uprawnia jedynie sąd do odstąpienia od wymierzenia kary, niezależnie od ogólnej reguły przewidzianej w treści art. 59 k.k. Zachowanie sprawcy działającego pod wpływem wyzywającego zachowania pokrzywdzonego pozostaje bezprawne. W okresie międzywojennym w judykaturze stwierdzano, że wyzywające zachowanie się napadniętego nie odbiera atakowi na cześć lub nienaruszalność cielesną cech przestępnych. Dodawano, że atak, nawet sprowokowany, nie przestaje być bezprawny, a przeto służy przeciw niemu prawo obrony koniecznej (art. 21 k.k.) ${ }^{66}$. Podobnie bezprawne jest działanie sprawcy, wobec którego pokrzywdzony odpowiedział naruszeniem nietykalności cielesnej lub zniewagą wzajemną. We wszystkich tych sytuacjach sąd może, ale nie musi odstapić od wymierzenia kary. W praktyce pojawić się może trudny do oceny problem czy odpowiedź na zniewagę była bezprawną retorsją, czy też realizacją prawa do obrony koniecznej przeciwko bezprawnemu zamachowi. W doktrynie wskazuje się, że decydujące znaczenie ma ustalenie ,czy działanie sprawcy, przynajmniej podmiotowo zmierzało do ochrony czci i godności, czy też zostało pojęte w celu wywarcia zemsty na napastniku"67. W judykaturze na gruncie k.k. z 1932 r. podkreślano, iż słowne zniewagi mogą uzasadniać stan obrony koniecznej wskazując, że np. dwukrotne uderzenie pokrzywdzonego po dokonanym już zamachu na godność osobistą i cześć sprawcy nie może stanowić ani obrony koniecznej, ani jej przekroczenia ${ }^{68}$.

„Wyzywające zachowanie” w znaczeniu potocznym to ,zachowanie zaczepne, zwracające na siebie uwagę, prowokujące, aroganckie, zuchwałe, impertynenckie, butne" ${ }^{" 69}$. W orzecznictwie w okresie międzywojennym wskazywano, że wyzywające zachowanie się, o jakim była mowa w treści art. $256 \S 2$ k.k. z 1932 r. polega na działaniu, które zdolne jest

65 M. Szymczak, Słownik języka polskiego, t. III, s. 51.

66 Wyrok SN z dnia 13 listopada 1934 r., sygn. akt III K 1101/34, OSN K 1935, nr 6, poz. 222 .

67 A. Marek, Kodeks karny..., s. 487-488; tenże, Obrona konieczna $w$ prawie karnym. Teoria i orzecznictwo, Warszawa 2008, s. 43.

68 Postanowienie SN z dnia 25 lutego 1965 r., sygn. akt Rw 1563/64, OSNPG 1965, nr 7, poz. 69.

${ }^{69}$ M. Szymczak, Stownik języka polskiego, t. III, s. 869; S. Dubisz, Uniwersalny słownik języka polskiego, t. IV, s. 715. 
wywołać odczucie własnego pokrzywdzenia przez znieważającego, a dokonana przez niego obraza pozostaje w związku przyczynowym $\mathrm{z}$ odczuciem tego pokrzywdzonego ${ }^{70}$. Podkreślano także w judykaturze na tle k.k. z 1932 r., że wyzywającym zachowaniem się jest nie tylko obraza osobista i naruszenie nietykalności cielesnej, lecz wszelkie działanie skierowane do obrażającego, choćby pośrednio lub w związku przyczynowym z doznaną obrazą i zdolne do wywołania u niego uczucia pokrzywdzenia $^{71}$. W doktrynie podnosi się, że wyzywające zachowanie ,nie musi samo zawierać elementów zniewagi czy innego czynu zabronionego, może to być zachowanie z punktu widzenia prawa karnego obojętne"72. Takim zachowaniem jest zachowanie pokrzywdzonego, który dopuszcza się uprzednio zniewagi wobec sprawcy, pomawia go, narusza nietykalność cielesną albo dopuszcza się innego czynu zabronionego.

W doktrynie podkreśla się, że „Wyzywające zachowanie się pokrzywdzonego musi mieć taki charakter z punktu widzenia ogólnie przyjętych i akceptowanych społecznie norm zachowania i systemów wartości. Nie wystarcza więc, iż jedynie sprawca odbierze je jako subiektywnie wyzy-

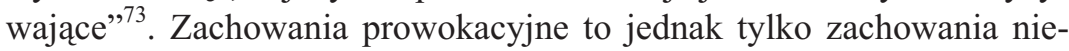
właściwe. Nie sposób do nich zaliczyć grzecznego zwrócenia sprawcy przestępstwa z art. 216 k.k. uwagi czy napomnienia go ${ }^{74}$.

W orzecznictwie zauważano, jeszcze na gruncie k.k. z 1932 r., że przepis art. 256 k.k. z 1932 r., będący odpowiednikiem obecnego art. 216 k.k., nie stawia żadnych ścisłych granic czasowych w kwestii uznania wzajemności zniewagi, ani nie warunkuje stosowania tego przepisu w zależności od ciężaru gatunkowego zniewag wzajemnych. W tej sytuacji, jak podkreślono, stosowanie art. 256 § 2 k.k. z 1932 r. jest wyłącznie uzależnione od tego, czy między obiema zniewagami istniał związek przyczynowy oraz od tego czy wzajemnie znieważający działał pod wpływem emocji i wrażeń wywołanych zniewagą przeciwnika ${ }^{75}$. Rozwijając tę

${ }^{70}$ Wyrok SN z dnia 4 maja 1933 r., sygn. akt II K 210/33, RPiE 1933, z. 4, s. 974.

71 Wyrok SN z dnia 4 lipca 1933 r., sygn. akt III K 482/33, OSN K 1933, nr 9, poz. 177; uchwała Najwyższego Sądu Wojskowego z dnia 13 listopada 1936 r., sygn. akt 357/36, WPP 1937, z. 1, s. 101, poz. 5.

2 J. Wojciechowski w: A. Wąsek, R. Zawłocki, Kodeks karny..., s. 1357.

${ }_{73}$ M. Filar, Pokrzywdzony (ofiara przestępstwa) w polskim prawie karnym materialnym, CZPKiNP 2002, z. 2, s. 77.

${ }^{74}$ J. Wojciechowski w: A. Wassek, R. Zawłocki, Kodeks karny..., s. 1356-1357.

75 Wyrok SN z dnia 12 października 1933 r., sygn. akt III K 839/33, RPiE 1934, z. 2 , s. 474 . 
myśl Najwyższy Sąd Wojskowy w jednym z orzeczeń stwierdził, że treść art. $256 \S 2$ k.k. z 1932 r. dając sądowi możliwość według jego uznania zwolnienia od kary nie wspomina o obowiązku badania przez sąd ciężaru gatunkowego zniewag wzajemnych ${ }^{76}$. Poglądy wyrażone we wspomnianych wyżej orzeczeniach zachowały, jak się wydaje, nadal aktualność.

W orzecznictwie międzywojennym wskazano także, że kompensacja zniewag może zachodzić jedynie wtedy, gdy zniewagi są wzajemne, tzn. gdy zniewagi od oskarżyciela doznał oskarżony, a nie jakakolwiek inna osoba, nawet najbliższa dla oskarżonego ${ }^{77}$. Poglądu tego nie podziela obecnie doktryna wskazując, że jakkolwiek prowokacja musi pochodzić od samego pokrzywdzonego, a nie od innej osoby, to nie musi być kierowana wprost do sprawcy i nie musi go bezpośrednio dotyczyć. Wyzywające zachowanie może być skierowane do osoby, która towarzyszy sprawcy, ale może także nie dotyczyć nikogo wprost i polegać na hałasowaniu bądź dopuszczaniu się nieobyczajnego wybryku. Nie usprawiedliwia natomiast zniewagi, którą sprawca kieruje do pokrzywdzonego w odpowiedzi na wyzywające się zachowanie innej osoby ${ }^{78}$.

W doktrynie podkreśla się jednak, że między prowokacją i zniewagą winien wchodzić w grę bliski związek czasowy zauważając, że przepis art. 216 k.k. nie wymaga tego jednak - co powoduje, że nie można wykluczyć sytuacji, gdy zniewaga będzie reakcją na prowokujące zachowanie się pokrzywdzonego odległe w czasie ${ }^{79}$. Ważne jest jednak, aby między prowokacją a zniewagą zaistniał związek przyczynowo-skutkowy. Świadectwem tego, że wolą ustawodawcy było to, aby między prowokacja, a także retorsją a zniewagą zaistniał taki związek jest sformułowanie zawarte w treści art. 216 § 2 k.k., gdzie mowa o ,wywołaniu zniewagi” oraz o „odpowiedzi na zniewagę".

W praktyce pojawić się może problem przekroczenia granic retorsji. Nastąpić to może w sytuacji, gdy pokrzywdzony w odpowiedzi na zniewagę nie tylko znieważył osobę, która dopuściła się takiego czynu, nie tylko naruszył jej nietykalność cielesną, lecz także pobił taką osobę,

76 Uchwała Najwyższego Sądu Wojskowego z dnia 2 października 1936 r., sygn. akt R 315/36, WPP 1937, z. 1, s. 91.

77 Orzeczenie SN z dnia 1 września 1922 r., sygn. akt 1505/22, Zbiór Orzeczeń 1922, poz. 220; por. także P. Hofmański, J. Satko, Przestępstwa przeciwko czci..., s. 191.

78 J. Wojciechowski w: A. Wąsek, R. Zawłocki, Kodeks karny..., s. 1357.

79 J. Wojciechowski w: A. Wąsek, R. Zawłocki, Kodeks karny..., s. 1357. 
powodując obrażenia ciała. W literaturze sformułowano pogląd, że przy takim przekroczeniu granic retorsji tym bardziej uzasadnione jest stosowanie wobec sprawcy możliwości odstapienia przez sąd od wymierzenia kary $^{80}$. Z tezą tą trudno się zgodzić, gdyż z treści art. $216 \S 3$ k.k. wyraźnie wynika, że tylko w przypadku, gdy sprawca odpowiedział naruszeniem nietykalności cielesnej lub zniewagą wzajemną sąd może odstapić od wymierzenia kary. W przypadku pobicia, pobicia ze skutkiem śmiertelnym fakt, że wcześniej oskarżony o takie czyny został znieważony może stanowić jedynie okoliczność łagodzącą. Ustawodawca wyraźnie przewiduje możliwość odstąpienia od wymiaru kary tylko w razie naruszenia nietykalności cielesnej i zniewagi wzajemnej, a nie w jakichkolwiek innych przypadkach.

Ustalenie, że zniewaga, o jakiej mowa w treści art. $216 \S 1$ k.k., została wywołana prowokacją lub też spotkała się z retorsją nie zobowiązuje sądu do odstąpienia od wymiaru kary, a jedynie daje taką możliwość. Tak więc odstąpienie od wymiaru kary w przypadku, o jakim mowa w treści art. 216 k.k., ma charakter fakultatywny, a nie obligatoryjny. W razie odstąpienia od wymiaru kary możliwe jest orzeczenie wobec sprawcy na podstawie art. $49 \S 1$ k.k. świadczenia pieniężnego, o jakim mowa w treści art. 39 pkt 7 k.k., na rzecz instytucji, stowarzyszenia, fundacji lub organizacji wpisanej do wykazu prowadzonego przez ministra sprawiedliwości, której podstawowym zadaniem lub celem statutowym jest spełnianie świadczeń na określony cel społeczny związany z ochroną dobra naruszonego lub zagrożonego przestępstwem, za które skazano sprawcę z przeznaczeniem na ten cel. Świadczenie to nie może przekroczyć dwudziestu tysięcy złotych. W doktrynie w sposób oczywiście omyłkowy podaje się niekiedy, kierując się tekstem pierwotnym i nie uwzględniając dokonanych w 2004 r. (Dz. U. 2004, Nr 243, poz. 2426, art. 1) zmian, że świadczenie to nie może przekroczyć trzykrotności najniższego miesięcznego wynagrodzenia w okresie orzekania w pierwszej instancji ${ }^{81}$. Począwszy od 1 stycznia 2002 r. w myśl ustawy z dnia 12 lutego 2010 r. o zmianie ustawy kodeks karny, ustawy kodeks karny wykonawczy oraz ustawy prawo ochrony i środowiska (Dz. U. 2010, Nr 40, poz. 227 z późn. zm.), odstępując od wymiaru kary w myśl art. 49 § 1 k.k., sąd będzie mógł orzec świadczenie pieniężne, wymienione w art. 39 pkt 7 k.k., na rzecz

80 J. Wojciechowski w: A. Wąsek, R. Zawłocki, Kodeks karny..., s. 1358.

81 Tak pisze J. Wojciechowski w wydanym w 2010 r. komentarzu: J. Wojciechowski w: A. Wąsek, R. Zawłocki, Kodeks karny..., s. 1356. 
Funduszu Pomocy Pokrzywdzonym oraz Pomocy Postpenitencjarnej, przy czym świadczenie to nie może przekroczyć sześciu tysięcy złotych. Wspomniana zmiana ma związek z powołaniem wspomnianego Funduszu. W uzasadnieniu wspomnianej ustawy wskazano, że powołanie Funduszu wyniknęło z faktu, że istniejące dotychczas rozwiązania dotyczące dysponowania nawiązkami i świadczeniami pieniężnymi, a więc środkami publicznymi nie realizowały w pełni zasad jawności i przejrzystości finansów publicznych, a w szczególności zasad kontroli finansowej ${ }^{82}$. Wskazano jednocześnie, że rozwiązanie to pozostaje w zgodzie z treścią przepisów decyzji Ramowej Rady z dnia 15 marca 2001 r. w sprawie pozycji ofiar w postępowaniu karnym (Dz. Urz. WE 2001/220/WSiSW).

W przypadku prowokacji i retorsji, ustawodawca w art. $216 \S 3$ k.k. przewiduje możliwość odstapienia od wymierzenia kary. W literaturze wskazuje się, że uzależnia w ten sposób karalność sprawcy zniewagi od zachowania się pokrzywdzonego zarówno poprzedzającego czyn przestępny w przypadku prowokacji, jak i następującego po nim w sytuacji retorsji. Wskazuje jednocześnie na konieczność wzięcia pod uwagę stanu psychicznego sprawcy, jego poczucia pokrzywdzenia, zdenerwowania wywołanego zachowaniem się późniejszego pokrzywdzonego ${ }^{83}$. Ratio legis zastosowania dyspozycji art. $216 \S 3$ k.k. jest odmienne w przypadku prowokacji od tego, które istnieje przy retorsji. W przypadku prowokacji należy mieć na względzie szczególną sytuację motywacyjną sprawcy, fakt, że podjęte przez niego działanie zostało spowodowane uprzednim postępowaniem pokrzywdzonego. W razie retorsji odstapienie od wymierzenia kary dyktowane jest przede wszystkim tym, że sprawca sam poniósł już ujemne konsekwencje swojego czynu ${ }^{84}$.

W sytuacji, gdy sprawca przy różnych okazjach znieważa pokrzywdzonego, np. wobec różnych osób, ewentualnie dopuszcza się znieważenia w kilku publikacjach prasowych, to jeśli te zachowania podjęte zostają w krótkich odstępach czasu, w wykonaniu z góry podjętego zamiaru i zachowana zostaje tożsamość pokrzywdzonego to należy przyjąć, w myśl art. 12 k.k., że doszło do znieważenia jednym czynem zabronionym. W sytuacji, gdy zniewaga dotyczy niejednego pokrzywdzonego, a kilku i nie ma możliwości przyjęcia, że sprawca działał w krótkich odstępach

82 Druk sejmowy nr 1854 Sejm RP IV kadencji.

83 J. Waszczyński w: I. Andrejew, L. Kubicki, J. Waszczyński, System prawa karnego..., s. 121-122.

${ }^{84}$ J. Raglewski, w: Kodeks karny..., red. A. Zoll, s. 835-836. 
czasu, wówczas może zachodzić przewidziany w treści art. 91 k.k. ciąg przestępstw. W doktrynie zauważa się, że jeśli sprawca w tym samym miejscu i czasie, pod adresem tej samej osoby używa słów o charakterze znieważającym lub wykonuje gesty poniżające godność pokrzywdzonego to popełnia jeden $\operatorname{czyn}^{85}$. W judykaturze, jeszcze na gruncie k.k. z 1932 r., stwierdzono podobnie wskazując, że ,czyn w postaci zniewagi słownej czy pisemnej, jako działanie sprawcy nie traci swej jedności faktycznej i prawnej przez to, że obejmuje atak na cześć kilku osób, wskazanych czy to imiennie, czy to zbiorowym określeniem lub przez znamiona wyróżniające obiektywnie o kogo chodzi" ${ }^{\prime 86}$. Znieważenie podczas tego samego wydarzenia jednym zwrotem kilku osób, np. mówiąc do nich „wy łajdaki" stanowi jeden czyn. Użycie w tym samym miejscu, ale pod adresem różnych osób różnych wyzwisk oznacza popełnienie kilku czynów ${ }^{87}$.

Sprawca znieważenia może swoim czynem wyczerpywać również znamiona zniesławienia. Nastąpi to w przypadku, gdy pomawiając inną osobę o takie postępowanie bądź właściwości, które może ją poniżyć w opinii publicznej lub narazić na utratę zaufania potrzebnego dla danego stanowiska, zawodu lub rodzaju działalności użyje słów obelżywych. W takim przypadku dojdzie do rzeczywistego zbiegu przepisów, co prowadzić musi do kumulatywnej kwalifikacji prawnej. Znieważający może także czynem swoim naruszać nietykalność cielesną, np. wymierzając komuś policzek. Zajdzie wówczas rzeczywisty zbieg przepisu prowadzący do kumulatywnej kwalifikacji prawnej. Warto w tym miejscu zauważyć, że na gruncie k.k. z 1932 r. Sąd Najwyższy stwierdził, że wypoliczkowanie lub zelżenie może mieścić w sobie nie tylko znamiona ściganego z oskarżenia prywatnego występku z art. 239 lub art. 256 k.k. z 1932 r., lecz także ściganego z urzędu prawa o wykroczeniach, będąc zamachem na dobro osobiste jednostki w postaci jej czci lub nietykalności osobistej, lecz także wybrykiem naruszającym porządek publiczny przez zakłócenie spokoju publicznego ${ }^{88}$.

85 J. Wojciechowski w: A. Wąsek, R. Zawłocki, Kodeks karny..., s. 1357; J. Raglewski, w: Kodeks karny..., red. A. Zoll, s. 840.

86 Wyrok SN z 25 stycznia 1935 r., sygn. akt III K 390/34, OSN K 1935, poz. 355 .

87 O. Górniok, w: O. Górniok i inni, Kodeks karny..., s. 1035.

${ }^{88}$ Wyrok SN z dnia 30 stycznia 1934 r., sygn. akt II K 1262/33, OSN K 1934, nr 6, poz. 117 . 
W przypadku, w którym sprawca grozi drugiej osobie, a groźby te wypowiada przy użyciu słów znieważających, wówczas zachodzi kumulatywny zbieg przepisów art. 216 k.k. lub 191 k.k. ${ }^{89}$ Niewłaściwy (pomijalny) zbieg przepisów zachodzi natomiast między treścią art. $216 \S 1$ a 197 k.k., nawet jeżeli zgwałcenie dokonane zostało z zamiarem znieważenia, dotknięcia godności osobistej ${ }^{90}$. Nie zachodzi rzeczywisty zbieg przepisów ustawy pomiędzy art. 216 k.k. a art. 135 §2, $136 \S 3$ i 4, 226 $\S 1,257,347 \S 1,350 \S 1$ k.k., gdyż w stosunku do wszystkich tych przepisów art. 216 k.k. stanowi lex generalis, a więc zachodzi pozorny zbieg przepisów.

Przestępstwo znieważenia zagrożone jest grzywną albo karą ograniczenia wolności. Grzywna może być orzeczona w myśl art. 33 § 1 i 3 k.k., w wymiarze od 10 do 540 stawek dziennych [górna granica stawek dziennych została podniesiona $\mathrm{z}$ dniem 8 czerwca $2010 \mathrm{r}$. z 360 stawek do 540 na podstawie art. 1 pkt 3 ustawy z dnia 5 listopada 2009 r. o zmianie ustawy Kodeks karny, ustawy Kodeks postępowania karnego, ustawy Kodeks karny wykonawczy, ustawy Kodeks karny skarbowy oraz niektórych innych ustaw (Dz. U. 2010, Nr 98, poz. 625)]. Stawka dzienna nie może być niższa od 10 złotych ani przekraczać 2000 złotych. Kara ograniczenia wolności może być orzeczona w wymiarze od 1 miesiąca do 12 miesięcy. Zarówno grzywna, jak i kara ograniczenia wolności mogą być orzeczone z warunkowym zawieszeniem ich wykonania w myśl art. $69 \S 1$ k.k. W przypadku orzeczenia warunkowego zawieszenia kary ograniczenia wolności w myśl art. $71 \S 1$ k.k. możliwe jest orzeczenie kary grzywny w wysokości do 135 stawek dziennych ${ }^{91}$.

Za znieważenie w typie kwalifikowanym, za pomocą środków masowego komunikowania dodatkowo możliwe jest orzeczenie kary pozbawienia wolności do 1 roku. Oczywiście wykonanie tej kary może być warunkowo zawieszone na mocy art. $69 \S 1$ k.k. W takiej sytuacji możliwe jest dodatkowo orzeczenie grzywny. W oparciu o treść art. $71 \S 1$ k.k. wysokość tej kary grzywny nie może przekroczyć 270 stawek dziennych (przed zmianą wprowadzoną wspomnianą ustawą z dnia 5 listopada 2009 r. Dz. U. 2009, Nr 206, poz. 1589 było to 180 stawek dziennych).

89 J. Raglewski, w: Kodeks karny..., red. A. Zoll, s. 841.

90 M. Surkont, Znieważenie z artykułu 181 a inne postacie zniewagi, NP. 1981, nr 2, s. 54; J. Raglewski, w: Kodeks karny..., red. A. Zoll, s. 841.

91 Przed zmianą wprowadzoną wspomnianą ustawą z dnia 5 listopada 2009 r. Dz. U. 2009, Nr 206, poz. 1589 było to 90 stawek dziennych. 
Wobec treści art. 66 § 1 i 2 k.k. z uwagi na wysokość ustawowego zagrożenia $\mathrm{z}$ art. $216 \S 2$ k.k. możliwe jest warunkowe umorzenie postępowania wobec sprawcy zniewagi dokonanej za pośrednictwem środków masowego komunikowania, oczywiście pod warunkiem, że wina i społeczna szkodliwość czynu nie są znaczne, okoliczności jego popełnienia nie budzą wątpliwości, a postawa sprawcy niekaranego za przestępstwo umyślne, jego właściwości i warunki osobiste oraz dotychczasowy sposób bycia uzasadniają przypuszczenie, że pomimo umorzenia postępowania będzie on przestrzegał porządku prawnego, a w szczególności nie popełni przestępstwa. W przypadku warunkowego umorzenia postępowania, a także w razie warunkowego zawieszenia kary sąd może zobowiązać skazanego na mocy art. $72 \S 1$ pkt 2 k.k. do przeproszenia pokrzywdzonego. W judykaturze podnosi się, że obowiązek przeproszenia pokrzywdzonego ma istotne znaczenie, gdy zostanie przyjęte, tj. gdy ofiara wybaczy sprawcy swej krzywdy ${ }^{92}$. W literaturze podnosi się, że obowiązek przeproszenia pokrzywdzonego spełnia funkcję weryfikatora oceny postawy sprawcy, a także służy zadośćuczynieniu pokrzywdzonemu za krzywdę wyrządzoną przestępstwem. Jest ono celowe wtedy, gdy wyrządzona przestępstwem krzywda jest tego rodzaju, że przeproszenie może być dla pokrzywdzonego pewną rekompensatą. Nie jest celowe nakładanie tego obowiązku, gdy sprawca już przed wydaniem orzeczenia o warunkowym umorzeniu postępowania przeprosi pokrzywdzonego ${ }^{93}$. Zauważa się, że obowiązek przeproszenia pokrzywdzonego posiada wymiar moralny i psychologiczny, jego wykonanie powinno dawać satysfakcję pokrzywdzonemu, forma przeproszenia zależna jest od decyzji sądu. Zgodzić się należy z poglądem, że nawet taki wymuszony akt przeprosin spełnia role wychowawczą, wskazuje bowiem skazanemu, że za popełnione w przyszłości przestępstwo może zostać zmuszony do przeprosin, chociaż nie daje to takiej satysfakcji pokrzywdzonemu jak akt niewymuszony ${ }^{94}$.

Zagrożenie karą przewidziane w odniesieniu do sprawców zniewagi umożliwia zastosowanie wobec nich dobrodziejstwa art. 59 § 1 k.k. i odstąpienie od wymiaru kary przy jednoczesnym zastosowaniu środków

92 Wyrok SA w Krakowie z dnia 16 sierpnia 2001 r., II Aka 162/2001, KZS 2001, z. 9, poz. 14.

93 A. Zoll w: Kodeks karny..., red. A. Zoll, s. 1013.

94 Kodeks karny. Część ogólna. Komentarz, red. J. Giezek, LEX 2007, uwagi do art. 72 . 
karnych, oczywiście pod warunkiem, że sąd dojdzie do przekonania, iż społeczna szkodliwość tego czynu nie jest znaczna. Pamiętać należy, że odstapienie od wymierzenia kary przewidziane jest także wprost $\mathrm{w}$ treści art. $216 \S 3$ k.k. W judykaturze na gruncie k.k. z 1969 r. wskazywano, że odstapienie od wymierzenia kary powinno następować wówczas, gdy „działanie sprawcy w swym zewnętrznym jakościowym kształcie nie różni się w sposób istotny od rodzaju i sposobu zachowania się pokrzywdzonego”. Wskazywano przy tym, że jeżeli „czyn sprawcy naruszający zakaz karny niejako w odpowiedzi na wyzywające się zachowanie pokrzywdzonego, ze względu na rodzaj, sposób, zakres i intensywność jego działania wyraźnie przekracza zawartość kryminalną uprzedniego zachowania się pokrzywdzonego, to wówczas odstapienie od wymierzenia kary z reguły nie powinno mieć zastosowania"95.

Tak więc sąd może poprzestać na orzeczeniu nawiązki czy świadczenia pieniężnego. Bardziej dotkliwy może się okazać zakaz zajmowania określonego stanowiska albo wykonywania określonego zawodu, jeżeli sprawca nadużył takowego stanowiska lub zawodu przy popełnieniu przestępstwa albo okazał, że dalsze zajmowanie takiego stanowiska bądź wykonywanie zawodu zagraża istotnym dobrom chronionym. Możliwe byłoby więc w odniesieniu do sprawcy zniewagi orzeczenie zakazu wykonywania zawodu dziennikarza w sytuacji, gdyby w swoich publikacjach dopuszczał się on zniewag. Orzekanie tego typu środka karnego winno mieć charakter wyjątkowy i następować jedynie w przypadku stwierdzenia, iż sprawca będący dziennikarzem wyraźnie nadużywa wykonywanego zawodu w celu znieważania innych. Jednorazowe stwierdzenie tego typu sytuacji wydaje się być niewystarczające. Podkreślić należy, że stwierdzeniu temu powinno także towarzyszyć przekonanie, iż sprawca narusza prawa i obowiązki dziennikarza, zwłaszcza stypizowane w treści art. 10 ust. $1 \mathrm{i}$ art. 12 ust. 1 PrPras.

Środkiem karnym, który sąd może zastosować odstępując na podstawie art. $59 \S 1$ k.k. od wymierzenia kary może być także przepadek przedmiotów, o jakim mowa w treści art. $44 \S 2$ k.k., czyli tych, które służyły lub były przeznaczone do popełnienia przestępstwa. Mogą być to ulotki, plakaty, tzw. bilbordy przeznaczone do popełnienia przestępstwa, przy czym podstawą orzeczenia przepadku może być także art. 37a PrPras

95 Wyrok SN z dnia 17 czerwca 1971 r., sygn. akt Rw 612/71, OSNKW 1971, z. 10 , poz. 159 . 
w sytuacji, gdy zniewaga popełniona została poprzez opublikowanie materiału prasowego. Orzeczenie przepadku materiału prasowego, przewidziane w art. 37a PrPras ma charakter fakultatywny i pozostawione jest uznaniu sądu. Może ono nastąpić zarówno w razie skazania za przestępstwo z art. 49a PrPras, jak i wówczas, kiedy publikacją materiału prasowego wyczerpano znamiona przestępstw z art. 212 § 1 lub 2 k.k. z 1997 r., względnie art. 216 § 2 k.k. z 1997 r. Ustawa traktuje materiał prasowy, w wyniku którego popełnione zostało przestępstwo, jako narzędzie przestępstwa, tj. przedmiot, który służył jego popełnieniu. Orzeczenie przepadku materiału prasowego - poprzez opublikowanie którego popełnione zostało przestępstwo - nie byłoby możliwe, gdyby nie zostało w sposób wyraźny przewidziane w art. 37a PrPras. Przepis art. 44 § k.k. z 1997 r. pozwala wprawdzie orzec przepadek przedmiotów stanowiących mienie ruchome, które służyły lub były przeznaczone do popełnienia przestępstwa, chyba że podlegają zwrotowi innemu podmiotowi. W myśl art. 44 $\S 6$ k.k. z 1997 r., jeśli przedmioty te nie stanowiły własności sprawcy, przepadek można orzec tylko w wypadkach przewidzianych w ustawie. Tak więc przepadek materiału prasowego z mocy art. 44 § 2 k.k. z 1997 r. byłby możliwy tylko wówczas, gdyby opublikowany materiał był własnością sprawcy. Tego rodzaju sytuacja, praktycznie rzecz biorąc, w odniesieniu do materiału prasowego mogłaby zaistnieć wyjątkowo. W ten sposób art. 37a PrPras zdaje się uzupełniać dyspozycje art. 44 § 2 i 6 k.k. z 1997 r., podobnie jak uzupełniał on rozwiązanie zawarte w art. 48 § 1 i 3 k.k. z 1969 r., przewidując możliwość przepadku materiału prasowego, stanowiącego przedmiot przestępstwa, lecz niebędącego własnością sprawcy. Przepadek przedmiotów sąd może orzec tytułem środka zabezpieczającego oraz wówczas, gdy społeczna szkodliwość czynu jest znikoma, a także w razie warunkowego umorzenia postępowania albo stwierdzenia, że zachodzi okoliczność wyłączająca ukaranie sprawcy czynu zabronionego (art. 100 k.k. z 1997 r.).

Ustawa prawo prasowe, nie zawierając przepisów wykonawczych, nie precyzuje sposobu wykonania przepadku materiału prasowego, a okoliczność ta w postępowaniu wykonawczym może mieć istotne znaczenie. Spośród rysujących się tu możliwości wykonania odrzucić należy wykonanie przepadku materiału prasowego poprzez jego zniszczenie. Ten sposób wykonania może się bowiem okazać niemożliwy do realizacji, a ponadto, przyjmując go, w sposób bezpowrotny zniszczono by przekazy mogące mieć wartość naukową, zarówno z punktu widzenia historyka czy historyka prawa lub literatury, jak i prasoznawcy czy uczonego 
zajmującego się problematyką prawa prasowego. Jako właściwsze wypada uznać wykonanie przepadku materiału prasowego przez złożenie tegoż materiału we wskazanym archiwum lub bibliotece z zastrzeżeniem ich nieudostępniania przez dość długi czas, np. stu lat. Można też zaakceptować wykonanie przepadku materiału prasowego, materiał ten nie przekracza liczby kilkunastu egzemplarzy i nie jest objętościowo obszerny, w formie pozostawienia tego materiału, będącego dowodem rzeczowym w sprawie, w aktach sprawy. Zasady wykonywania środka karnego w postaci przepadku przedmiotu regulują art. 187-195 k.k.w. z 1997 r. Wykonanie środka karnego przepadku przedmiotów należy do właściwego urzędu skarbowego.

W treści art. $216 \S 4$ k.k. przewidziano możliwość orzeczenia nawiązki w razie skazania za przestępstwo znieważenia za pomocą środków masowego komunikowania (art. 216 k.k.) na rzecz pokrzywdzonego, Polskiego Czerwonego Krzyża albo na inny cel społeczny wskazany przez pokrzywdzonego. Ustawa dopuszcza jednak możliwość orzeczenia tylko jednej nawiązki, a nie wielu na każdy z przewidzianych przez ustawę celów. Nawiązka może być orzeczona w wysokości do 100000 złotych zgodnie z treścią ustawy z dnia 8 października 2004 r. (Dz. U. 2004, Nr 243, poz. 2426).

Przestępstwa z art. $216 \S 1$ i 2 k.k. ścigane są z oskarżenia prywatnego, o czym stanowi art. $216 \S 5$. Tak więc pociagnięcie sprawcy do odpowiedzialności zależy od woli pokrzywdzonego, któremu pozostawiono ocenę czy jego cześć została naruszona oraz jakie środki trzeba zastosować dla jej ochrony. Pozostawienie pokrzywdzonemu inicjatywy ścigania przestępstw z art. $216 \S 1$ i 2 k.k. wiąże się z ich szczególnym charakterem, gdyż są to przestępstwa naruszające bezpośrednio osobisty interes pokrzywdzonego, a jedynie pośrednio interes publiczny. W literaturze słusznie wskazuje się, że w przypadku przestępstw przeciwko czci cel kompensacyjny bądź restytucyjny udzielanej ochrony przeważa nad klasycznymi funkcjami represji karnej. Pokrzywdzony w takich sprawach, w pierwszym rzędzie, zmierza do przywrócenia swojego dobrego imienia w oczach opinii publicznej. Tak więc kara wymierzana sprawcy nie jawi się jako najważniejszy element, przywracający pokrzywdzonemu zniesławieniem jego cześć ${ }^{96}$. Pokrzywdzony, jako oskarżyciel prywatny w sprawie

96 W. Kulesza, Zniestawienie..., s. 146; B. Wróblewski, Cześć, godność, honor, Wilno 1936, s. 35. 
o zniesławienie jest „,gospodarzem procesu karnego o ochronę czci” - od jego wyłącznej woli zależy więc samo wszczęcie procesu, jak i popieranie wniesionego aktu oskarżenia ${ }^{97}$.

Akt oskarżenia w sprawie o znieważenie może wnieść jednak prokurator jeśli uzna, że wymaga tego interes społeczny. W takim przypadku postępowanie toczy się z urzędu.

Zważywszy, że przestępstwo zniesławienia ścigane jest z oskarżenia prywatnego, przedawnienie karalności w odniesieniu do tych czynów następuje z upływem roku od czasu, gdy pokrzywdzony dowiedział się o osobie sprawcy przestępstwa, nie później jednak, niż z upływem 3 lat od czasu jego popełnienia (art. $101 \S 2$ k.k.). Jeśli jednak w tym okresie zostało wszczęte postępowanie przeciwko osobie, karalność popełnionego przez taką osobę przestępstwa ustaje z upływem 5 lat od zakończenia tego okresu (art. 102 k.k.).

$\mathrm{W}$ razie śmierci pokrzywdzonego, jego prawa, w myśl art. $52 \S 1$ k.p.k., mogą wykonywać osoby najbliższe, a w wypadku ich braku lub nieujawnienia - prokurator, działając z urzędu. W razie, gdy pokrzywdzonym jest małoletni albo ubezwłasnowolniony całkowicie lub częściowo, jego prawa, zgodnie z art. $51 \S 2$ k.p.k., wykonuje jego przedstawiciel ustawowy albo osoba, pod której pieczą pokrzywdzony pozostaje. Z wnioskiem o ściganie sprawcy zniesławienia, podobnie jak w każdej innej sprawie z oskarżenia prywatnego, może wystapić prokurator, jeżeli uzna, że wymaga tego interes społecznych (art. 60 § 1 k.p.k.). Wówczas postępowanie toczy się z urzędu, a pokrzywdzony, jeśli przedtem wniósł oskarżenie prywatne, korzystać będzie z praw oskarżyciela posiłkowego (art. $60 \S 2$ k.p.k.). Może także do czasu przewodu sądowego złożyć oświadczenie, że będzie działał w charakterze oskarżyciela posiłkowego. Nie jest jednak konieczne, aby pokrzywdzony w takiej sytuacji wystapił w charakterze oskarżyciela posiłkowego.

97 J. Sadomski, Ochrona czci (dobrego imienia) w polskim prawie cywilnym i karnym - analiza porównawcza, w: Stosowanie prawa. Księga jubileuszowa z okazji XX-lecia Instytutu Wymiaru Sprawiedliwości, red. A. Siemaszko, Warszawa 2011, s. 154. 


\title{
Freedom of Speech and Insulting Language
}

\begin{abstract}
Summary
The crime of using insulting language protects human dignity (its external aspect) from such infringements that in terms of culturally determined and commonly accepted standards express contempt for an individual, irrespective of his or her feelings. The offence of using insulting or offensive language, refers to an act of disparagement, or offensive behavior towards somebody. An insult expressed via the mass media results in more serious consequences. The public nature of an act referred to in Art. 216, section 1 of Penal Code means that it was committed in a manner allowing it to be noted by a number of people that cannot be determined in advance. Therefore, a qualified type of insult involves one committed via the mass media. The ratio legis of this construction is rather obvious, as an insult committed via the mass media has a larger range, and a larger impact area.
\end{abstract}


